\title{
Technical and economic viability of manual harvesting coffee yield maps
}

\author{
Rafael de Oliveira Faria' (iD), Fábio Moreira Silva ${ }^{1}$ (D), Gabriel Araújo e Silva Ferraz ${ }^{1}$ (D), Miguel Angel Diaz Herrera² (D), \\ Brenon Diennevan Souza Barbosa1 ${ }^{\text {(D) }}$, Diego José Carvalho Alonso1 ${ }^{\text {(D) }}$, Daniel Veiga Soares ${ }^{1}$ (iD)
}

\author{
${ }^{1}$ Universidade Federal de Lavras/UFLA, Departamento de Engenharia Agrícola/DEA, Lavras, MG, Brasil \\ ${ }^{2}$ Universidade Surcolombiana/USCO, Faculdade de Engenharia, Neiva, Huila, Colômbia \\ Contact authors: rafael.ufla@gmail.com, b.diennevan@outlook.com,dj.ufla@gmail.com, daniel.veiga@rehagro.com.br, famsilva@deg.ufla.br, gabriel.ferraz@deg.ufla.br, \\ migueldiaz@estudante.ufla.br \\ Received in November 13, 2019 and approved in June 15, 2020
}

\section{ABSTRACT}

Precision coffee growing is a concept that implies the use of precision agriculture techniques in coffee plantations. For the coffee growing, the precision electronic resources coupled to the harvesters are very scarce. Thereby, the harvest of coffee plantations that compose the grid sampling for generation of thematic maps can be performed manually. The aim of the present study was to generate a linear regression model to estimate the time required to harvest, estimate the labor costs to harvest manually the georeferenced sample points for generation of coffee yield maps. The study was performed in a coffee area of 56 hectares using two sampling points per hectare, totaling 112 points, being evaluated four coffee plants for each point. The manual harvest of the points was performed by four rural workers with experience in the coffee harvest. Afterwards, the collected volume was measured by a graduated container and the times were obtained by the digital stopwatch. Based on the data obtained in the field, a linear correlation model was established between the harvest time of each sampling point and the yield of the point, whose $\mathrm{R}^{2}$ value was 78.27 , cost was $\mathrm{R} \$ \mathbf{8 . 9 2}$ per point. These results are relevant for estimating the amount of labor force required to generate manually harvest yield maps according to the producer's coffee yield estimate, contributing to the closure of the precision coffee growing cycle.

Key words: Precision agriculture; crop mapping; field efficiency; costs.

\section{INTRODUCTION}

Coffee production in Brazil is highly representative in the current country's economy, covering a planted area with more than 2.21 million ha, almost identical to the area planted in 2016. The increase in the planted area each year is due to the increased yield from the investment by producers in new technologies (CONAB, 2017).

According to Ferraz et al., (2017a), the modernization of the agricultural sector, mainly in the coffee sector is being driven by precision agriculture (PA) in coffee plantations. The PA is based on spatial variability in the area under cultivation, in contrast to conventional agriculture that works with crop means, thus reducing losses in the application of inputs and reduction of damages to the environment (Molin et al., 2007). The site-specific management techniques were adopted in order to reduce the operating costs of an agricultural activity, thus optimizing the enterprise (Costa et al., 2014).

For the annual crops, the use of soil analysis techniques and application of georeferenced agricultural inputs are routine in the implantation and conduction of the crop (Dalchiavon et al., 2017). The set of management techniques aimed at standardizing plant yield and the sustainable use of natural resources is called PA (Bernardi et al., 2015).

For perennial crops, predominantly the coffee crop, the precision management techniques are still limited. The conventionally used way to sample coffee crop properties is made using random sampling, as prescribed by classical, nonspatial statistics (Carvalho et al., 2017).

Precision coffee farming (PC) is a concept that implies the use of precision agriculture techniques in coffee plantations (Silva; Alves, 2013). The understanding on spatial variability in the crop requires a greater amount of information obtained from representative grid sampling (Ferraz et al., 2012a). Beyond the georeferenced soil analyses and variable rate fertilizer applications, the yield mapping is extremely important for the precision coffee growing cycle, especially in order to compare the applied products with the localized coffee yield and to know the crop yield patterns intensities (Faulin; Molin, 2007; Ferraz et al., 2012a, 2017b; Figueiredo et al., 2013; Molin et al., 2010; Molin; Faulin; Stanislavski, 2009; Silva; Alves, 2013).

The use of yield mapping can improve crop management, such as soil sampling intensity, by indicating the areas with the highest and lowest sample (Ferraz et al., 2017a; Molin et al., 2007).

For the coffee growing, the precision electronic resources coupled to the harvesters are very scarce, especially for the generation of yield maps Based on the above, the coffee harvest that compose the grid sampling for generation of these maps can be performed manually. Therefore, the study of the costs, time and labor force required to apply this methodology should be studied 
(Ferraz et al., 2012b). The aim of the present study was to develop a linear regression model to estimate the time required to harvest, estimate the labor costs to harvest manually the georeferenced sample points for generation of coffee yield maps.

\section{MATERIAL AND METHODS}

The experiment was performed in June 2017 at Fazenda Samambaia, in the municipality of Santo Antônio do Amparo, South of the State of Minas Gerais, Brazil, at the geographical coordinates of $20^{\circ} 58^{\prime} 19.92 " \mathrm{~S}$ and $44^{\circ} 53^{\prime} 24.18^{\prime \prime} \mathrm{W}$. Experimental area has 56 hectares of coffee (Coffea arabica L.) from the cultivar Acaiá IAC 474-19, being implanted in 2000 with spacing of $3.6 \mathrm{~m}$ between rows and $0.8 \mathrm{~m}$ between plants and average height of $1.8 \mathrm{~m}$, with pruning in 2015.

The non-uniform grid sampling of two points per ha totaled 112 points and was recommended for precision coffee growing, besides pointed in the studies of optimal grid index (Carvalho et al., 2017; Ferraz et al., 2017b; Figueiredo et al., 2017). The commercial software of precision agriculture called FARMWORKS was used for pointing and creating the grid sampling and sample points, later transferred in a text file with geographic coordinate data and identification of points. Navigation in the field was assisted by an Android smartphone with global navigation satellite system (GNSS) and the C7 GPS Malha application, developed by the Geomatics Laboratory of the Federal University of Santa Maria (UFSM, 2017).

For each georeferenced sampling point in the center of the coffee street, four coffee plants were evaluated by the complete harvest, with two plants on the right and another two on the left side of the point. The manual harvesting and cleaning was performed by four rural workers (one for each plant) with experience in the coffee harvest, accompanied by an agricultural technician for data annotation, evaluation of fruit maturation and navigation in the area using the smartphone. The methodology followed by (Santinato et al., 2015; Silva et al., 2010) for the manual harvest was performed according to the practice of each worker with their proper personal protective equipment (PPE) and cloth and after manual cleaning using sieves. The collected volume was then measured by a container graduated in milliliters (liters.plant ${ }^{-1}$ ) and the times were obtained through the digital stopwatch of the smartphone.

The time was counted from the moment when the workers began placing the cloths under the plants, until the moment after the cleaning and the pouring of the collected coffees inside the graduated bucket. The total volume was divided by the number of harvested plants, obtaining the average crop loading in the plant at the sampling point and the average volume for each worker. The average time of catcher's walking from one sampling point to another was gathered using the digital stopwatch.

The time and yield data of the point were tabulated on a spreadsheet in the office, creating the charts and trend lines. The analysis of variance and linear regression was compiled using the SISVAR software (Ferreira, 2011).

Based on the linear regression model generated by SISVAR, it was compared with the results of the obtained averages and the values obtained in other studies, such as (Cirillo, 2007) (Silva et al., 2011), being possible to validate and verify the results.

To calculate the labor costs, besides the fixed salary, the social security charges should be included, such as: Lengthof-service guarantee fund (FGTS), National institute of social security (INSS), vacation, thirteenth salary, holiday bonus plus a value related to contractual termination, totaling $42 \%$ of the base salary. The salary average practiced in the study region is a minimum wage and a half for workers who make the manual harvest and the technician who will follow and navigate (Cunha et al., 2016).

The calculation of the daily rate for each worker was calculated based on the aforementioned values and divided by the number of days worked in the month, which in the average of the region is 26 days. From the averages of sampled points that the workers performed in a daily period, it is possible to calculate the cost of each point, being the daily rates paid to the workers divided by the average number of points that the group of workers performed at the end of the day.

\section{RESULTS AND DISCUSSION}

Based on the analysis of variance and linear regression performed in the SISVAR field data, the coefficient of variation of $25.64 \%$ and the linear correlation model between the harvest time and the average yield in liters of each plant from the sample point performed by a man were established, whose $\mathrm{R}^{2}$ value is $86.16 \%$, being the observed average points and the trend line shown in Figure 1. In Equation 1 is shown the linear regression of the estimated averages.

When comparing the data of the three experiments with results described in Table 1 , it is verified that the values vary according to the crop loading, as described in Equation 1. The results obtained in this study (EXP column) are very similar in relation to the data obtained by (Silva et al., 2011) in plot A (column S1), thus showing that the linear regression model indicated by Equation 1 is also representative for other crops. Harvest times may vary according to crop height, slope, worker ability, walking distance from one point to the other, among others. 


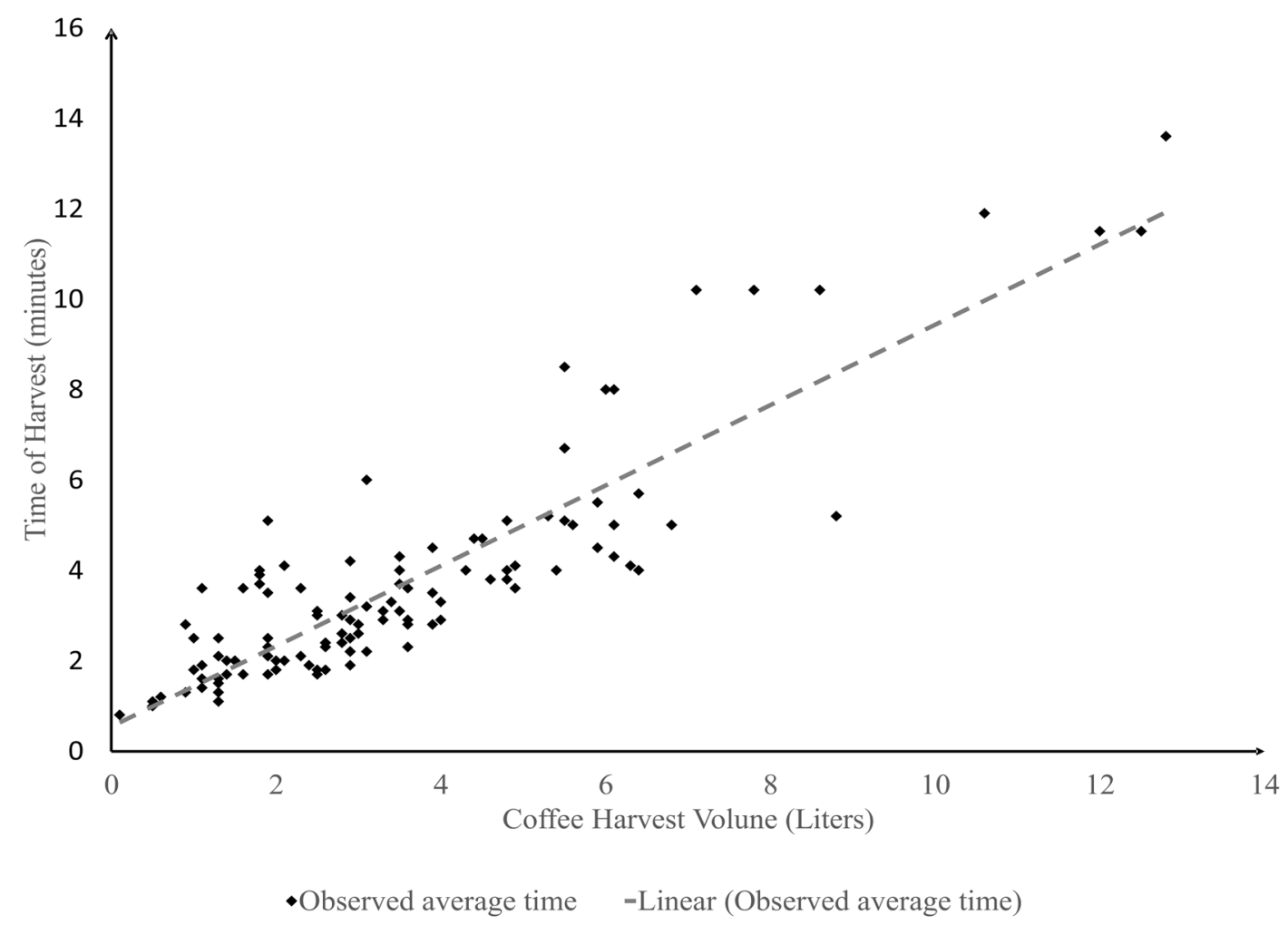

Figure 1: Averages of time observed in relation to the harvested volume and the average time estimated from the linear regression.

$\mathrm{T}=0.931524 \mathrm{~V}+0.397946$

Where:

$\mathrm{T}$, time in decimal minutes

$\mathrm{V}$, estimated average volume per plant

Table 1: Crop loading (liters.plants ${ }^{-1}$ ) and harvest time (hour) for the present study results in column EXP. Results of the study by (Cirillo, 2007) Plots C1=A, C2-B E C3=C. Results of the study by (Silva et al., 2011), S1=A, S2=B and S3=C.

\begin{tabular}{cccccccc}
\hline & EXP & C1 & C2 & C3 & S1 & S2 & S3 \\
\hline $\begin{array}{c}\text { Crop loading } \\
\text { (liters.plants }\end{array}$ ) & 3.55 & 1.72 & 1.72 & 1.72 & 3.79 & 1.73 & 4.18 \\
$\begin{array}{c}\text { harvest time } \\
\text { (hour) }\end{array}$ & 0.062 & 0.056 & 0.054 & 0.058 & 0.071 & 0.059 & 0.056 \\
\hline
\end{tabular}

Through the Equation 1, the crop loading average of $3.55 \mathrm{~L}$ per plant will result in estimated time of 0.0618 hour per point. With the walking time among points of 0.0282 hour and considering the average of 43 sample points per day, the running time of the harvest will be 2.658 hour, the total walking time among points of 1.2111 hour, totaling an actual operating time real of 3.87 effective working hours.

The low field efficiency is due to the times required for street switching, location of the predefined sample points in the office and guided by the $\mathrm{C} 7$ Campeiro application and the
GNSS, transport of the harvested coffees to the carrier, stop for lunch, coffee, personal needs, among others.

The walking of sampling points were performed by four catchers and one field technician, which, for the southern region of Minas Gerais, Brazil, has the average salary of rural workers for the coffee crop of 1.5 minimum wages with the increase of $42 \%$ social charges, as described by (Cunha et al., 2016). The value of the minimum wage in 2017 was $R \$ 937.00$, totaling R \$1995.81 with charges, for a monthly workday of 26 days, resulting in $\mathrm{R} \$ 76.76 \mathrm{man}^{-1}$ day $^{-1}$, both for the catcher and the agricultural technician.

The 112 sampling points were run in two and a half days, being gathered 41 points in the first day, 45 points in the second and 25 points in the third until lunchtime, averaging 43 points per day.

According to Batista, Sampaio and Silva (2014), the operating cost expresses the relationship between cost and capacity of work or yield. Considering the 43 points per day as working capacity for the five employees and the daily cost of $\mathrm{R} \$ 383.80$, it results in the operating cost of the field survey of $\mathrm{R} \$ 8.92$ per sampling point, or $\mathrm{R} \$ 17.85$ per hectare to generate the yield mapping, which is lower than the cost of soil or leaf analysis, justifying this simple and manual method of data acquisition.

After obtaining the field data, it is possible to generate the yield maps of the coffee plantation based on previously georeferenced points. The geostatistical analysis can be 
performed in different ways and computer software. After the data processing, it is possible to create the thematic map with information of locations with higher or lower yield (Silva; Alves, 2013). Therefore, coffee growers can verify the factor that caused this yield variation and coordinate which actions should be taken for the next harvest in the places with low yield (Ferraz et al., 2012b).

Up to the present, there is no embedded equipment on the coffee harvesters that are viable and reliable, however, the producer can generate the yield maps of the coffee plantation using the method described in the present study (Ferraz et al., 2012b).

According to Ferraz et al. 2012b, the advantages of the thematic yield maps obtained by the used methodology lead to several improvements in the coffee cultivation, besides closing the precision coffee growing cycle since the soil and leaf sampling, application of fertilizers and limestone at variable rate, localized control of weeds, among others. It can also be used in the coordination of coffee harvesting similarly as in manual, mechanized or semi-mechanized operations.

In manual harvesting, the maps can contribute to estimate yield, hire labor force for the harvest and negotiate with the worker on the measured price of that crop. In semimechanized harvesting, it will also be important to estimate harvesters and necessary labor force, besides the outsourcing needs of any crop. In mechanized harvesting, they can be used to plan the distance between the loading for the emptying of the harvester's reservoir, or in the case of machines that do not have the own reservoir, the transshipment sizing (tractor + truck) in order to reduce unnecessary stops and maneuvers.

In view of this, yield mapping is extremely important for precision coffee growing, being necessary to disseminate the techniques to coffee growers who already perform part of the precision management and for those who still work with classic non-georeferenced coffee growing.

\section{CONCLUSIONS}

In the present study, a linear regression equation was developed and validated with $\mathrm{R}^{2}$ of $86.16 \%$, which makes possible to estimate the time required to harvest a coffee plant for generation of thematic yield maps.

It was possible to devise the value of the sampling point to perform the yield mapping, in which the estimated value was R 8.92 for each sampling point. Thus, for the present study, with two sampling points per hectare were collected, it resulted in a value of $\mathrm{R} \$ 17.85$ per hectare.

\section{ACKNOWLEDGEMENTS}

UFLA, Samambaia Farm, Bom Jardim Coffee Seeds, FAPEMIG and CAPES.

\section{REFERENCES}

BATISTA, J. V.; SAMPAIO, O. B.; SILVA, F. F. da. A influência de fatores climáticos e ambientais sobre saúde de trabalhadores florestais. Revista em Agronegócios e Meio Ambiente, 7(2):359-390, 2014.

BERNARDI, A. C. C. de et al. Ferramentas de agricultura de precisão como auxílio ao manejo da fertilidade do solo. Cadernos de Ciência \& Tecnologia, 32(1/2):211-227, 2015.

CARVALHO, L. C. C. et al. Comparação entre amostragem foliar convencional e de precisão para análise de micronutrientes na cafeicultura. Coffee Science, 12(2):272-281, 2017.

CIRILLO, J. E. Avaliação de tempo efetivo da derriça mecanizada e manual do café, na região de Garça.

Revista científica eletônica de agronomia, $6(11): 0-5$, 2007.

COMPANHIA NACIONAL DO ABASTECIMENTO - CONAB. Acompanhamento da safra brasileira café. 2017. Available in: <http://www.conab.gov.br/ OlalaCMS/uploads/arquivos/17_09_21_17_00_05_cafe setembro_2017.pdf >. Access in: November 27, 2017.

COSTA, N. R. et al. Produtividade de laranja correlacionada com atributos químicos do solo visando a zonas específicas de manejo. Pesquisa Agropecuaria Tropical, 44(4):391-398, 2014.

CUNHA, J. P. B. et al. Economic viability for different coffee harvest systems. Coffee Science, 11(3):416-425, 2016.

DALCHIAVON, F. C. et al. Variabilidade espacial de atributos químicos do solo cultivado com soja sob plantio direto. Revista de Ciências Agroveterinárias, 16(2):144154, 2017.

FAULIN, G. D. C.; MOLIN, J. P. Utilização dos conceitos da agricultura de precisão na cultura do café (Coffea arabica L .). 5 simposio de pesquisas dos cafes do Brasil, 1998:70-75, 2007.

FERRAZ, G. A. E. S. et al. Agricultura de precisão no estudo de atributos químicos do solo e da produtividade de lavoura cafeeira. Coffee Science, 7(1):59-67, 2012a.

FERRAZ, G. A. E. S. et al. Geostatistical analysis of fruit yield and detachment force in coffee. Precision Agriculture, 13(1):76-89, $2012 \mathrm{~b}$.

FERRAZ, G. A. E. S. et al. Methodology to determine the soil sampling grid for precision agriculture in a coffee field. Dyna, 84(200):316-325, 2017. 
FERREIRA, D. F. Sisvar: A computer statistical analysis system. Ciência e Agrotecnologia, 35(6):1039-1042, 2011.

FIGUEIREDO, V. C. et al. Levantamento da fertilidade do solo de lavouras cafeeiras em produção, no sul de minas gerais. Coffee Science, 8(3):306-313, 2013.

FIGUEIREDO, V. C. et al. Analysis of spatial variability of force detachment of coffee fruits in central pivot. Coffee Science, 12(2):84-92, 2017.

MOLIN, J. P. et al. Variação espacial na produtividade de milho safrinha devido aos macronutrientes e à população de plantas. Revista Brasileira de Milho e Sorgo, 6(3):309-324, 2007.

MOLIN, J. P. et al. Test procedure for variable rate fertilizer on coffee. Acta Scientiarum. Agronomy, 32(4):569-575, 2010.

MOLIN, J. P.; FAULIN, G. D. C.; STANISLAVSKI, W. M. Yield mapping and variable rate of fertilizers for coffee in brazil. Acta Horticulturae, (824):261-266, 2009.

SANTINATO, F. et al. Economic analysis of harvesting coffee using repeat operations. Coffee Science, 10(3):402-411, 2015.

SILVA, F. M. et al. Efeitos da colheita manual na bienalidade do cafeeiro em Ijaci, Minas Gerais. Ciencia e Agrotecnologia, 34(3):625-632, 2010.

SILVA, F. M. et al. Café: Mecanização da colheita. I Simpósio de Pesquisa dos Cafés do Brasil. Lavras I Simpósio de Pesquisa dos Cafés do Brasil., 281-327, 2011.

SILVA, F. M. da; ALVES, M. C. de. Cafeicultura de Precisão. Lavras: Editora UFLA, 2013. 227p.

UFSM, L. DE G. Software CR Campeiro: C7 GPS Malha para a plataforma Android. 2017. Available in: <http://www.crcampeiro.net>. Access in: August, 20, 2017. 